NASA/TM—2011-217105

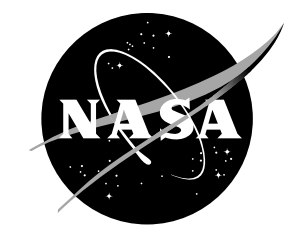

Resilient and Corrosion-Proof Rolling Element Bearings Made From Superelastic Ni-Ti Alloys for Aerospace Mechanism Applications

Christopher DellaCorte, Ronald D. Noebe, Malcolm K. Stanford, and Santo A. Padula Glenn Research Center, Cleveland, Ohio 


\section{NASA STI Program . . . in Profile}

Since its founding, NASA has been dedicated to the advancement of aeronautics and space science. The NASA Scientific and Technical Information (STI) program plays a key part in helping NASA maintain this important role.

The NASA STI Program operates under the auspices of the Agency Chief Information Officer. It collects, organizes, provides for archiving, and disseminates NASA's STI. The NASA STI program provides access to the NASA Aeronautics and Space Database and its public interface, the NASA Technical Reports Server, thus providing one of the largest collections of aeronautical and space science STI in the world. Results are published in both non-NASA channels and by NASA in the NASA STI Report Series, which includes the following report types:

- TECHNICAL PUBLICATION. Reports of completed research or a major significant phase of research that present the results of NASA programs and include extensive data or theoretical analysis. Includes compilations of significant scientific and technical data and information deemed to be of continuing reference value. NASA counterpart of peer-reviewed formal professional papers but has less stringent limitations on manuscript length and extent of graphic presentations.

- TECHNICAL MEMORANDUM. Scientific and technical findings that are preliminary or of specialized interest, e.g., quick release reports, working papers, and bibliographies that contain minimal annotation. Does not contain extensive analysis.

- CONTRACTOR REPORT. Scientific and technical findings by NASA-sponsored contractors and grantees.
- CONFERENCE PUBLICATION. Collected papers from scientific and technical conferences, symposia, seminars, or other meetings sponsored or cosponsored by NASA.

- SPECIAL PUBLICATION. Scientific, technical, or historical information from NASA programs, projects, and missions, often concerned with subjects having substantial public interest.

- TECHNICAL TRANSLATION. Englishlanguage translations of foreign scientific and technical material pertinent to NASA's mission.

Specialized services also include creating custom thesauri, building customized databases, organizing and publishing research results.

For more information about the NASA STI program, see the following:

- Access the NASA STI program home page at http://www.sti.nasa.gov

- E-mail your question via the Internet to help@ sti.nasa.gov

- Fax your question to the NASA STI Help Desk at $443-757-5803$

- Telephone the NASA STI Help Desk at 443-757-5802

- Write to: NASA Center for AeroSpace Information (CASI) 7115 Standard Drive Hanover, MD 21076-1320 
NASA/TM-2011-217105

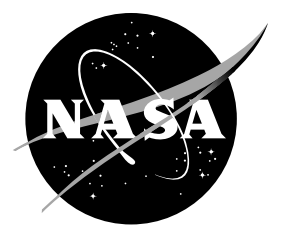

\section{Resilient and Corrosion-Proof Rolling Element Bearings Made From Superelastic Ni-Ti Alloys for Aerospace Mechanism Applications}

Christopher DellaCorte, Ronald D. Noebe, Malcolm K. Stanford, and Santo A. Padula Glenn Research Center, Cleveland, Ohio

Prepared for the

2011 Symposium on Rolling Element Bearings

sponsored by the American Society of Testing and Materials

Anaheim, California, April 13-14, 2011

National Aeronautics and

Space Administration

Glenn Research Center

Cleveland, Ohio 44135 


\section{Acknowledgments}

The authors wish to acknowledge the financial support from the NASA Engineering and Safety Center (NESC) and NASA's Subsonic Rotary Wing and Supersonics Projects and to Timken Corporation for permission to publish the preliminary RCF results.

This report contains preliminary findings, subject to revision as analysis proceeds.

Level of Review: This material has been technically reviewed by technical management.

Available from

NASA Center for Aerospace Information 7115 Standard Drive

Hanover, MD 21076-1320
National Technical Information Service 5301 Shawnee Road Alexandria, VA 22312

Available electronically at http://www.sti.nasa.gov 


\title{
Resilient and Corrosion-Proof Rolling Element Bearings Made From Superelastic Ni-Ti Alloys for Aerospace Mechanism Applications
}

\author{
Christopher DellaCorte, Ronald D. Noebe, Malcolm K. Stanford, and Santo A. Padula \\ National Aeronautics and Space Administration \\ Glenn Research Center \\ Cleveland, Ohio 44135
}

\begin{abstract}
Mechanical components (bearings, gears, mechanisms) typically utilize hard materials to minimize wear and attain long life. In such components, heavily loaded contact points (e.g., meshing gear teeth, bearing ball-raceway contacts) experience high contact stresses. The combination of high hardness, heavy loads and high elastic modulus often leads to damaging contact stress. In addition, mechanical component materials, such as tool steel or silicon nitride exhibit limited recoverable strain (typically less than 1 percent). These material attributes can lead to Brinell damage (e.g., denting) particularly during transient overload events such as shock impacts that occur during the launching of space vehicles or the landing of aircraft. In this paper, a superelastic alloy, $60 \mathrm{NiTi}$, is considered for rolling element bearing applications. A series of Rockwell and Brinell hardness, compressive strength, fatigue and tribology tests are conducted and reported. The combination of high hardness, moderate elastic modulus, large recoverable strain, low density, and intrinsic corrosion immunity provide a path to bearings largely impervious to shock load damage. It is anticipated that bearings and components made from alloys with such attributes can alleviate many problems encountered in advanced aerospace applications.
\end{abstract}

\section{Introduction}

The industrial revolution of the 18th and 19th centuries brought forth impressive new mechanical and materials technologies that vastly improved manufacturing and transportation but also created the need for an improved understanding of phenomena (stresses and deformations) encountered in highly loaded contacts (e.g., in bearings and gears). Hertz developed some of the earliest analytical stress models for contacting surfaces such as ball bearing-raceways and the wheel-rail interface (Ref. 1). The Hertz model is sufficiently general to include the radii of curvature of the surfaces, their elastic moduli and the contact loads (Ref. 2). Hertz's calculations for contact stress, for example, explain what happens when two solid bodies contact one another and how damage occurs when the deformations and stresses exceed allowable material limits.

Such models have guided the design of mechanical components. For instance, Hertz calculations are used to estimate the contact stress in bearings between rolling elements and raceways and also between the contacting points of meshing gear teeth. Using "Hertz" stress levels as a guide, the contact geometry and material properties can be tailored to minimize stresses and distribute the load. Over decades of experimental development, so-called "hertzian" contacts in machine elements have evolved to incorporate hard materials with commensurately high stiffness and relatively low values of ductility and recoverable elastic strain (Ref. 3). Though this approach yields long life and low friction such components are susceptible to localized damage during high load events.

Contacts that occur between curved surfaces made from hard and stiff materials result in very small contact areas and high local stresses. In a bearing subjected to a shock or other type of overload situation, denting of the precision raceway can readily occur and is called Brinell type damage (Ref. 4). Brinell denting of surfaces often leads to rough operation and premature fatigue failure and is avoided largely by limiting overloads and tailoring contact geometry to reduce peak stress. The use of less rigid, softer 
materials could reduce local contact stresses but would also lead to the loss of load capacity, structural rigidity, higher operating friction and generally lower fatigue life. Much of these negative effects can be traced to excessive deformation in the contact areas and susceptibility of softer, less rigid surfaces to be damaged by foreign particles like dirt and hard wear debris. Based upon the prevailing and successful use of hard, rigid materials in mechanical components one can infer that hard and stiff is preferable to soft and less rigid.

An alternate path to improved bearing design might be to employ materials that are sufficiently hard to mitigate wear but at the same time sufficiently compliant to minimize contact stress levels during highload events. In effect, what may be more desirable than the use of hard, stiff materials for mechanical component applications is the use of hard but highly compliant materials. Such a material may seem like a paradox since hardness and rigidity typically go hand-in-hand. Furthermore, acceptable fatigue resistance is paramount for long life. Interestingly, but not widely recognized, the desire for such materials is not a new concept.

In the 1950s, T.L. Oberle was among the first to put forth that a relationship exists between wear resistance and the ratio of material hardness $(\mathrm{H})$ to elastic modulus $(\mathrm{E})$, the $\mathrm{H} / \mathrm{E}$ ratio (Ref. 5). He called this ratio the Modell. In his landmark paper, he suggested that improved machine wear life could be attained not through the development of ultra hard materials alone but rather through the identification and development of materials more resistant to indentation-induced damage. Oberle assumed that the best materials for mechanical components were the ones that exhibited the high hardness needed to provide abrasion resistance but yet were of sufficiently low elastic modulus to limit localized stresses that occur when hard particles enter a contact. Recognizing that high hardness and high elastic moduli are generally coincident material properties, Oberle considered hard chrome plating on softer steel substrates as an alternate means to achieve a high effective Modell.

More recently, other researchers have followed this example to purposefully engineer coatings and surface treatments to enhance the H/E ratio and tribological performance (Ref. 6). Ceramic coatings, surface conversion treatments, and bonded metallic films on more elastic substrates have been extensively evaluated. It has been observed that coatings that perform best in sliding are not always the hardest but rather those with a high $\mathrm{H} / \mathrm{E}$ ratio (Refs. 5 and 6). Though Oberle and more recent researchers seem to have concentrated upon sliding contact, their approach has equal if not more compelling arguments when applied to concentrated rolling contacts like bearings, gears and other mechanical components.

Engineering bearings from materials with high Modell could enhance performance in several ways. Reduced elastic modulus will result in a higher degree of elastic deformation (strain) under a given load leading to increased contact area and reduced peak hertz stress. Thus, in theory, higher load levels could be endured without exceeding local stress limits, provided that high levels of elastic strain are accommodated. Such a high Modell bearing should also be similarly less susceptible to debris denting. Of course, adequate material hardness would be required to mitigate more general types of wear such as abrasion. Successful bearing materials must also be compatible with lubricants such as oil or grease and be of sufficient strength to withstand typical machine loads. Other equally critical attributes include the ability to be manufactured to great precision and of sufficient quality to provide reasonable fatigue properties.

The fact that Oberle expressed his desire for the development of high Modell materials so long ago and no such materials have yet been identified suggests that such an avenue to improved wear performance is not possible. In fact, the recent proliferation of silicon nitride ball/steel race hybrid bearings appears to embody an approach opposite to the one promoted by Oberle. The adoption of ceramic rolling elements increases hardness and modulus and results in reduced contact areas with mating raceways leading to higher hertz stresses. Hybrid bearings are widely recognized as being prone to raceway denting because of these factors and care must be taken to limit overall load levels. For the aerospace industry, shock loads can be unavoidable and a recent example of such a failure can be readily found (Ref. 7). 
This paper evaluates the premise of using high Modell materials for bearings, gears and other mechanical components by considering materials from the family of shape memory alloys. When properly prepared, some of these materials are hard, yet have a relatively low apparent elastic modulus and exhibit superelastic behavior. As an example, a nickel-titanium alloy, NITINOL 60 originally developed by the U.S. Navy, is evaluated for use in rolling element bearings. A series of experiments is conducted to establish the feasibility of using such materials for mechanical components especially with respect to applications involving high dynamic loads.

In the remainder of this paper an ordered intermetallic binary Nickel-Titanium alloy is introduced that appears to satisfy Oberle's requirement of high Modell while offering additional significant benefits such as greatly extended elasticity, immunity from corrosion, tribological compatibility and reduced density. Its feasibility for use in bearings and components is evaluated through a variety of mechanical and materials tests.

\section{Materials}

\section{Background}

Binary Nickel-Titanium (Ni-Ti) alloys are in widespread use in the medical and dental industries in applications where their biocompatibility and unique superelastic and Shape Memory Effect (SME) characteristics are readily exploited (Refs. 8 and 9). More recently in the aerospace industry, shape memory alloy activated structures have been proposed and demonstrated for such applications as general flow control, adaptive inlets and nozzles, variable geometry chevrons, variable camber fan blades, and flaps and other hinged components (Refs. 10 and 11). These applications capitalize upon the temperature dependent, large reversible strain change inherent in near equi-atomic Ni-Ti alloys (containing approximately $55 \mathrm{wt} \%$ nickel) even when opposed by high constraining forces. The use of such alloys in mechanical components is problematic on two fronts. Near equi-atomic Ni-Ti alloys lack the dimensional stability required for precision mechanical assemblies like bearings and gears. When used above and below their transformation temperature, large dimensional changes, due to shape memory effects, are observed. Further, such alloys have low hardness leading to high wear in tribological applications.

Equi-atomic Ni-Ti alloys, however, only represent a small fraction of compositions in this family. Within the Ni-Ti system, and in closely related materials systems, there exist compositions that, when appropriately heat treated and processed, exhibit high levels of hardness and dimensional stability. For selected applications, the shape memory effect can be tailored to occur well below conceivable use temperatures. An example of one such alloy is the nickel-rich NITINOL 60 (60NiTi) alloy that contains 60 -wt $\%$ nickel (55 at.\%) and 40- wt\% titanium. Whereas the more commonly known NITINOL 55 (55NiTi) is soft and exhibits remarkable shape memory effects, NITINOL 60 can be made dimensionally stable and easily hardens to Rockwell C 60 or higher through appropriate heat treatment. Recently, advanced manufacturing methods have been used to produce bearing quality rolling elements from NITINOL 60 that display excellent tribological behavior (Refs. 12 and 13).

Table I lists relevant material properties for 60NiTi alongside the shape memory alloy 55NiTi and more conventional bearing materials. While $60 \mathrm{NiTi}$ has about the same hardness as M50 tool steel and other bearing alloys it displays a relatively low apparent modulus similar to titanium. This yields a Modell $(\mathrm{H} / \mathrm{E})$ for $60 \mathrm{NiTi}$ that is about twice that of hardened steel and satisfies Oberle's goal for a bulk material with enhanced Modell. In addition to having a high Modell, 60NiTi also exhibits certain characteristics of shape memory alloys that are pertinent to applications in highly loaded contacts, namely superelasticity. Superelasticity here is defined as a material's ability to undergo large (more than 3 percent) strains that are fully recoverable. Typical bearing steels exhibit recoverable strain limits of less than 1 percent. 
TABLE I.-NOMINAL PROPERTIES FOR CONVENTIONAL BEARING ALLOYS AND 55NiTi AND 60NiTi

\begin{tabular}{|c|c|c|c|c|c|}
\hline Property & 60NiTi & $55 \mathrm{NiTi}$ & $440 \mathrm{C}$ & $\mathrm{Si}_{3} \mathrm{~N}_{4}$ & $\mathrm{M}-50$ \\
\hline Density & $6.7 \mathrm{~g} / \mathrm{cc}$ & $6.5 \mathrm{~g} / \mathrm{cc}$ & $7.7 \mathrm{~g} / \mathrm{cc}$ & $3.2 \mathrm{~g} / \mathrm{cc}$ & $8.0 \mathrm{~g} / \mathrm{cc}$ \\
\hline Hardness & $56-62 \mathrm{HRC}$ & $35-40 \mathrm{HRC}$ & $58-62 \mathrm{HRC}$ & $1300-1500 \mathrm{Hv}$ & $60-65 \mathrm{HRC}$ \\
\hline Thermal conductivity $\mathrm{W} / \mathrm{m}-{ }^{\circ} \mathrm{K}$ & 18 & 19 & 24 & 33 & $\sim 36$ \\
\hline Thermal expansion & $\sim 12.4 \times 10^{-6} /{ }^{\circ} \mathrm{C}$ & $\sim 10 \times 10^{-6} /{ }^{\circ} \mathrm{C}$ & $10 \times 10^{-6} /{ }^{\circ} \mathrm{C}$ & $2.6 \times 10^{-6}$ & $\sim 11 \times 10^{-6} /{ }^{\circ} \mathrm{C}$ \\
\hline Magnetic & Non & Non & Magnetic & Non & Magnetic \\
\hline Corrosion resistance & Excellent & Excellent & Marginal & Excellent & Poor \\
\hline Tensile/Flexural strength & $\sim 1000 \mathrm{MPa}$ & $\sim 900 \mathrm{MPa}$ & $1900 \mathrm{MPa}$ & $\begin{array}{l}600-1200 \mathrm{MPa} \\
\text { (Bend Strength) }\end{array}$ & $2500 \mathrm{MPa}$ \\
\hline Young's Modulus & $\sim 95 \mathrm{GPa}$ & $\sim 100 \mathrm{GPa}$ & $200 \mathrm{GPa}$ & $310 \mathrm{GPa}$ & $210 \mathrm{GPa}$ \\
\hline Poisson's ratio & $\sim 0.34$ & $\sim 0.34$ & 0.3 & 0.27 & 0.30 \\
\hline Fracture toughness & $\mathrm{TBD}^{\mathrm{a}}$ & TBD & $22 \mathrm{MPa} / \sqrt{\mathrm{m}}$ & $5-7 \mathrm{MPa} / \sqrt{\mathrm{m}}$ & $20-23 \mathrm{MPa} / \sqrt{\mathrm{m}}$ \\
\hline Maximum use temp & $\sim 500^{\circ} \mathrm{C}$ & $\sim 300^{\circ} \mathrm{C}$ & $\sim 400^{\circ} \mathrm{C}$ & $\sim 1100^{\circ} \mathrm{C}$ & $\sim 400{ }^{\circ} \mathrm{C}$ \\
\hline Electrical resistivity & $\begin{array}{c}\sim 80 \times 10^{-6} \\
\Omega-\mathrm{cm}\end{array}$ & $\begin{array}{c}\sim 80 \times 10^{-6} \\
\Omega-\mathrm{cm} \\
\end{array}$ & $\begin{array}{c}\sim 36 \times 10^{-6} \\
\Omega-\mathrm{cm}\end{array}$ & Insulator & $\begin{array}{c}\sim 60 \times 10^{-6} \\
\Omega-\mathrm{cm} \\
\end{array}$ \\
\hline
\end{tabular}

aTBD means "to be determined."

In the following sections, a series of experiments are presented that are designed to determine the potential for a high Modell material like 60NiTi to offer enhanced performance in applications such as bearings, gears or other mechanical components. Hardness, tribology, fatigue, and basic materials tests are considered. These sub-component and indirect tests are used to support the concept of making shock resistant components utilizing high Modell materials. Furthermore, this paper explores the potential for other such materials to offer engineering solutions to longstanding problems and vulnerabilities facing precision mechanical systems.

\section{Materials}

\section{Processing History}

This study focused on a single composition of NiTi, namely $60 \mathrm{NiTi}$. Several diverse processing paths were used to fabricate samples for the various tests used to evaluate the potential of this material for bearing, gear and other mechanical components. The goal was not to determine the best form of $60 \mathrm{NiTi}$ but rather to simply and conveniently generate a basic set of properties for this material.

$60 \mathrm{NiTi}$ balls were manufactured via a high temperature proprietary powder metallurgy process roughly similar to that described in the literature (Ref. 14). Pre-alloyed 60NiTi powder was hot isostatically pressed (HIPed) into rough, spherical ball blanks that were then ground, hardened, polished, and lapped to produce high quality (Grade 5) bearing balls $12.7 \mathrm{~mm}$ in diameter. A multi-step thermal process (heat treatment) was used to enable rough grinding of the bearing balls in a softened state followed by lapping to a very fine surface finish in a final hardened condition. The finished 60NiTi ball specimens, shown in Figure 1, were bright and shiny in appearance and resembled conventional polished steel balls.

The $60 \mathrm{NiTi}$ plates were processed via two slightly different methods. In one case, plates were processed by vacuum induction skull melting followed by casting in graphite molds. Once removed from the molds, the ingots were subjected to hot isostatic pressing to consolidate any internal voids remaining from the casting process. Figure 2 shows a collection of castings from which test specimens were cut. Further references to this material in will be as "cast" $60 \mathrm{NiTi}$. In the second method, an electro-slag re-melt process followed by hot rolling was used to produce plate material. Further references to this material will be as "hot-rolled" $60 \mathrm{NiTi}$. All samples regardless of starting condition were given a final hardening heat treatment $\left(980^{\circ} \mathrm{C}\right.$ for $\left.1 \mathrm{~h}\right)$ followed by oil or water quench. Some preliminary properties for the $60 \mathrm{NiTi}$ were also measured in the as-received condition (i.e., cast or hot-rolled), for comparison to the heat-treated material. 


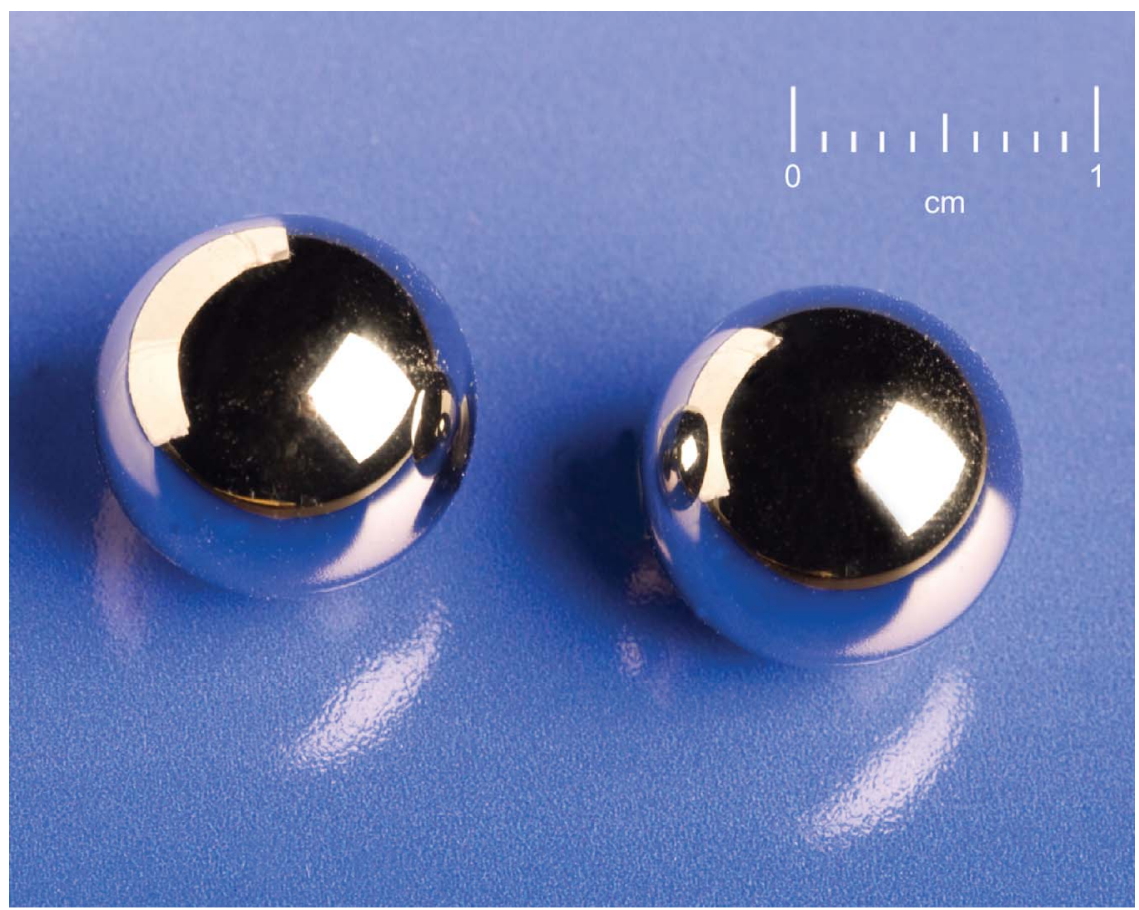

Figure 1.-Photograph of $60 \mathrm{NiTi}$ polished ball specimens prior to testing.

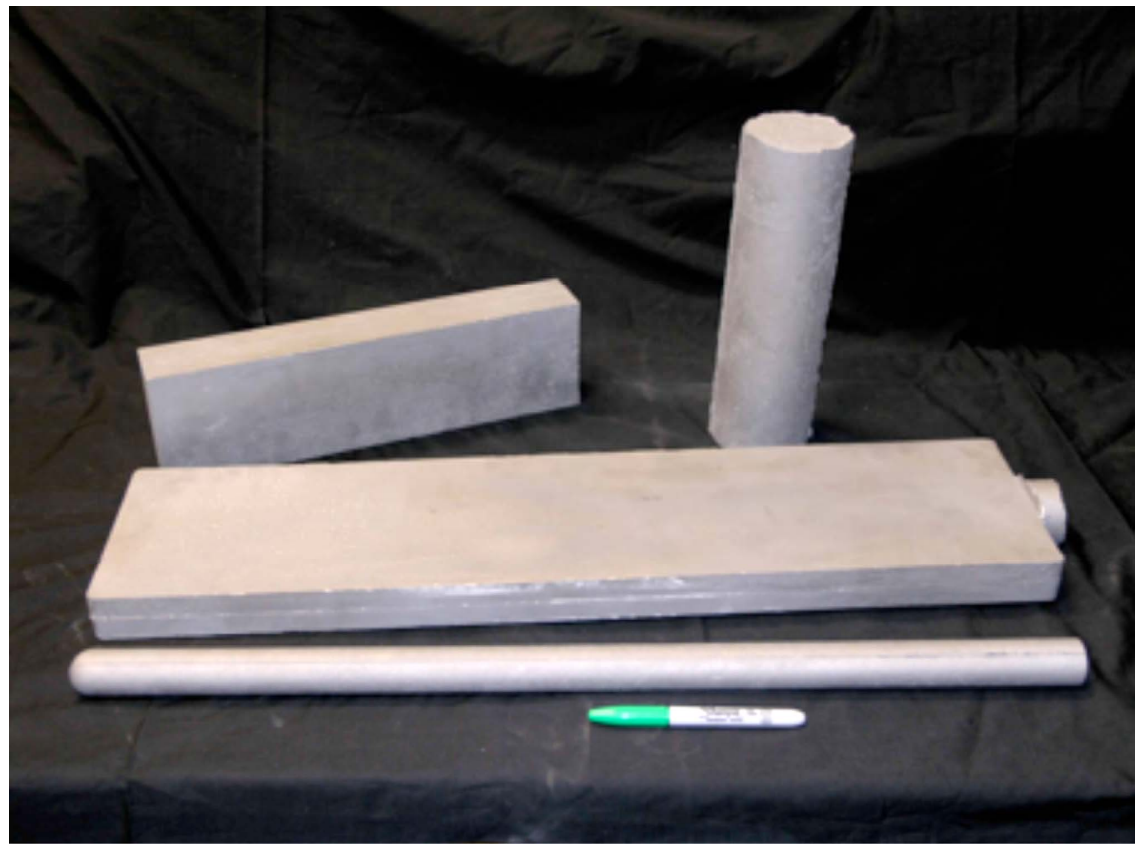

Figure 2.-60NiTi cast ingots from which test specimens were fabricated.

Density was measured to be $6.71 \mathrm{~g} / \mathrm{cm}^{3}$ and is about 15 percent lower than the corresponding value for tool steel. Figure 3 shows the microstructure for a cross section of the $60 \mathrm{NiTi}$ ball specimens in its final hardened and polished condition. Hardness measurements indicated values in the range of 58 to 62 on the Rockwell C scale (HRC). Figure 4 shows representative photomicrographs for several of the material conditions considered. 


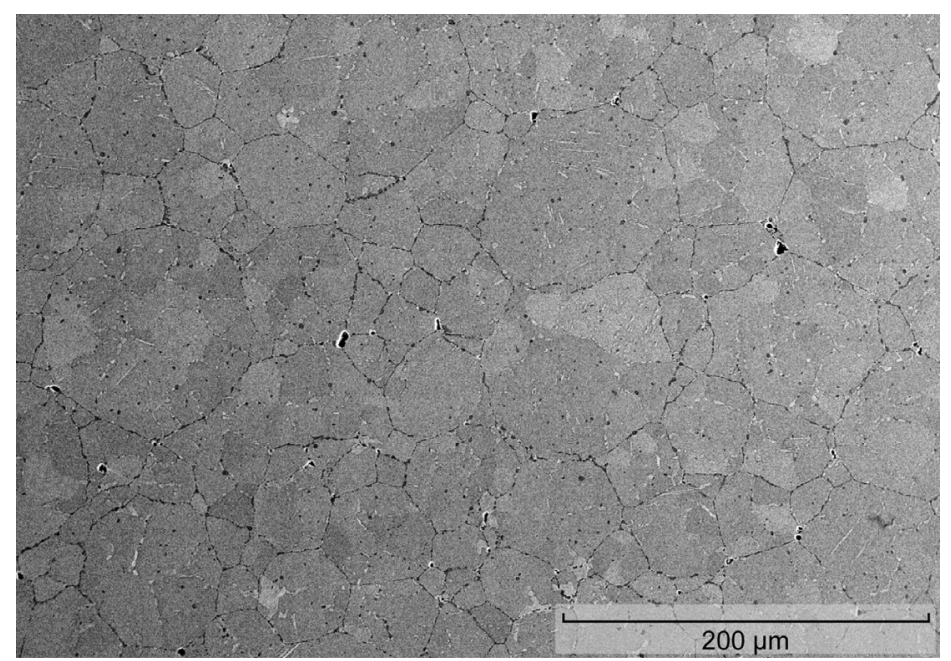

Figure 3.-Cross-section photomicrograph of a $60 \mathrm{NiTi}$ ball showing grain structure typical for powder metallurgy processed materials.
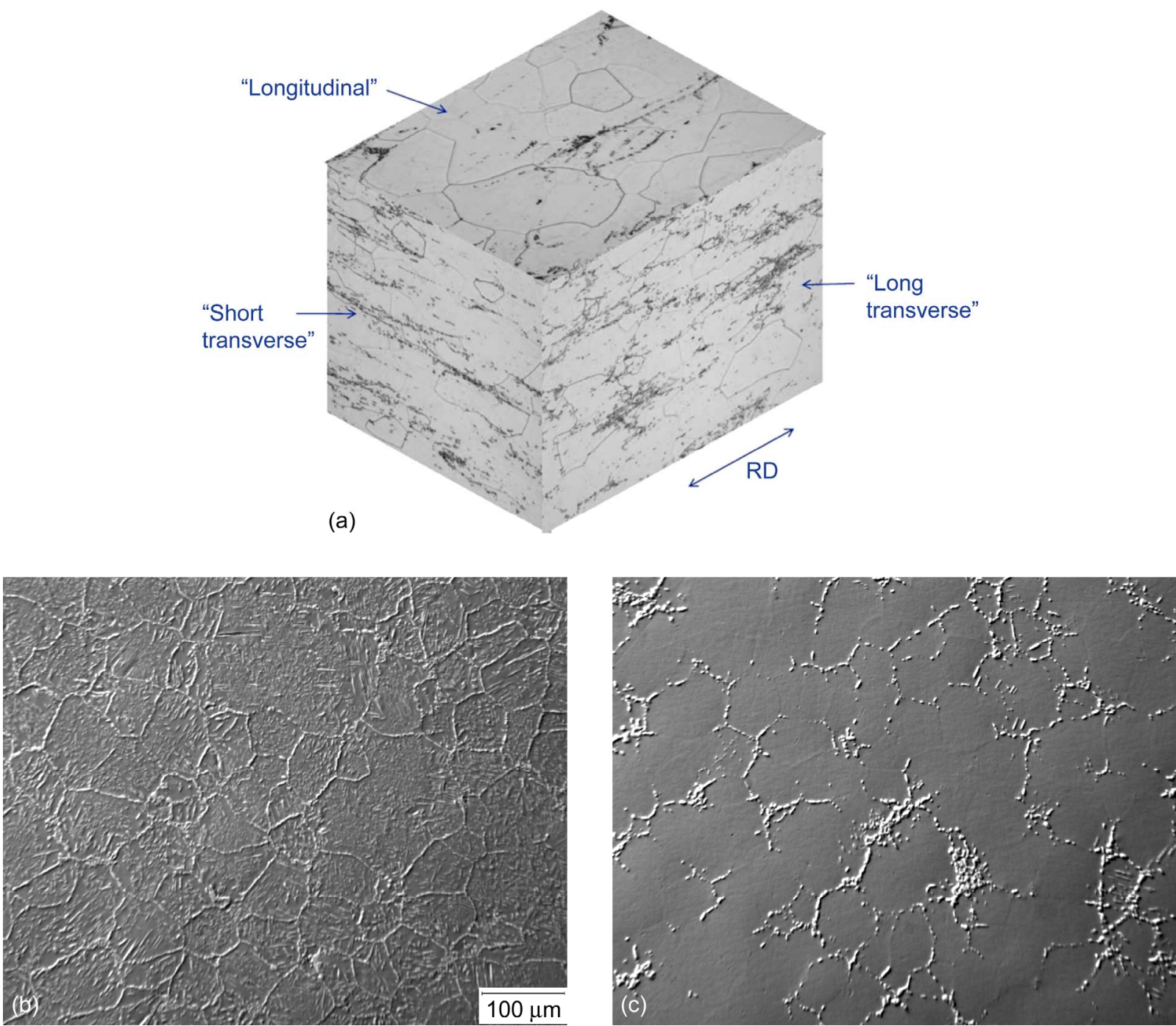

Figure 4.-Cross section of $60 \mathrm{NiTi}$ : (a) isometric view of hot-rolled material; (b) microstructure of cast and HIPed material; and (c) microstructure of the cast and HIPed material after heat-treatment. 
For comparison purposes, conventional bearing materials were also examined. Plates made from M50 tool steel, 440C stainless steel, and the cobalt alloy Stellite 6B (in the precipitation hardened condition), were prepared and tested. With regards to atmospheric attack, 440C stainless steel is considered a corrosion resistant bearing material while Stellite 6B is considered corrosion "proof". Additionally, indenter balls from bearing grade $\mathrm{Si}_{3} \mathrm{~N}_{4}$ were procured from a commercial source.

\section{Experimental Evaluations of 60NiTi-Procedures and Results}

Several conventional and unconventional experimental tests were conducted to determine the feasibility of using a high Modell, superelastic material such as $60 \mathrm{NiTi}$ as a candidate material for mechanical components. These included conventional hardness tests, Brinell damage threshold tests, compression tests, rolling contact fatigue tests, and Spiral Orbit Tribometer (SOT) tribology tests. The primary goal of these tests was to evaluate the potential for making bearings and machine components from a superelastic and high Modell material that can better withstand dynamic overload forces without incurring permanent damage.

\section{Hardness Test}

Standard indentation (Rockwell C indenter) hardness tests were performed on the 60NiTi samples in the as received and also in the hardened conditions. In this hardness test, a pyramidal diamond indenter is forced into the sample under a $150 \mathrm{~kg}$ load. The penetration depth after indent is automatically measured and reported as a numeric hardness value on the Rockwell C scale (HRC). Soft materials like mild steel, annealed nickel alloys, and titanium typically register in the HRC 15 to 30 range. Hardened bearing steels typically yield values between HRC 50 to 65 . The hardness results for the hot-rolled material were essentially the same as the cast material. Therefore no distinction among these processing routes is hereafter made. The test material is simply designated as either "hardened" or "as-received."

As-received 60NiTi was fairly soft and had a hardness value of about HRC 24 to 30 . Following hardening heat-treatment, its hardness increased to HRC 58 to 60. Despite such a large increase in hardness, casual laboratory measurements and observations suggest that the material was dimensionally stable during the heat treatment with no significant observed warping, shrinkage, expansion or distortion. For comparison, the hardness values for typical bearing materials were also measured and catalogued in Table II. $440 \mathrm{C}$ stainless steel exhibited hardness that mirrored $60 \mathrm{NiTi}$, with hardness ranging from HRC 58 to 60 . M50 tool steel was a bit harder, HRC 60 to 63. The precipitation hardened cobalt alloy, Stellite 6B, was slightly softer, HRC 44 to 46 . For long life and maximum load capacity, material hardness above HRC 55 is generally preferred for bearing and gear applications.

TABLE II.-ROCKWELL C (HRC) HARDNESS FOR 60NiTi AND TYPICAL BEARING MATERIALS

\begin{tabular}{|l|c|}
\hline \multicolumn{1}{|c|}{ Material } & Rockwell C Hardness, HRC \\
\hline Stellite 6B & 44 to 46 \\
\hline $440 \mathrm{C}$ & 58 to 60 \\
\hline M50 & 60 to 63 \\
\hline $60 \mathrm{NiTi}$ & 58 to 62 \\
\hline
\end{tabular}




\section{Brinell Indentation Hardness Test}

The Brinell hardness test consists of pressing a large diameter $(12.7 \mathrm{~mm})$ ball into the surface of a plate of test material, beyond the yield strength, resulting in a round and permanent dent. The diameter of the ball and dent along with the load are used to calculate the Brinell hardness. The higher the number, the more resistant a material is to indentation damage. In these tests, $\mathrm{Si}_{3} \mathrm{~N}_{4}$ balls were used to indent plates of $60 \mathrm{NiTi}, 440 \mathrm{C}$ and M50 bearing steels, and Stellite 6B. A multi-purpose load frame was used for this test. The test load was applied gradually over a $120 \mathrm{sec}$ period and varied from 10 to $3000 \mathrm{~kg}_{\mathrm{f}}$ depending upon the material tested. The test set-up is shown in Figure 5.

The data (Table III) indicated that $60 \mathrm{NiTi}$ had the highest Brinell hardness at 530, followed by M50 at 500, 440C at 435. Stellite 6B exhibited the lowest value of 310. Clearly, 60NiTi has an excellent resistance to indentation damage but the Brinell number alone does not give a full picture of $60 \mathrm{NiTi}$ 's ability to resist damage, which is more fully delineated in the following tests.

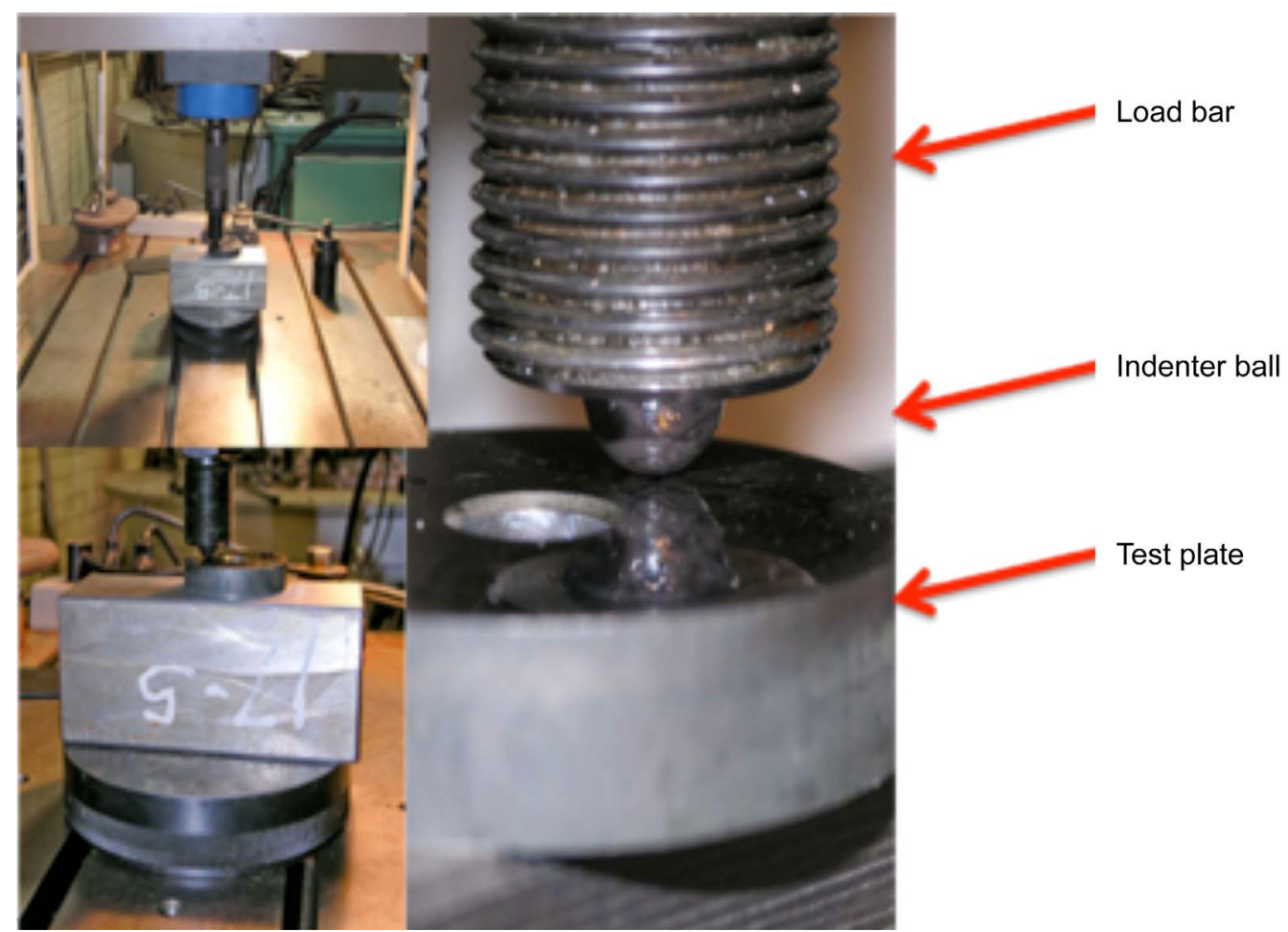

Figure 5.-Brinell hardness test set up used to press balls of $\mathrm{Si}_{3} \mathrm{~N}_{4}$ or $60 \mathrm{NiTi}$ into various plate materials to measure indentation resistance.

TABLE III.-BRINELL HARDNESS AND MODELL (BHN/E) FOR 60NiTi AND TYPICAL BEARING MATERIALS

\begin{tabular}{|c|c|c|c|}
\hline Material & $\begin{array}{c}\text { Elastic modulus, } \\
\text { GPa (MPsi) }\end{array}$ & $\begin{array}{c}\text { Brinell hardness } \\
\text { number, BHN }\end{array}$ & $\begin{array}{c}\text { Modell } \\
\text { number }\end{array}$ \\
\hline Stellite 6B & $210(30.4)$ & 302 & 9.9 \\
\hline $440 \mathrm{C}$ & $207(30)$ & 434 & 14.5 \\
\hline M50 & $207(30)$ & 493 & 16.4 \\
\hline 60NiTi & $100(15)$ & 531 & 37.9 \\
\hline
\end{tabular}


TABLE IV.-HERTZ CONTACT STRESSES AND CONTACT DIAMETER AT THE THRESHOLD

LOAD FOR VARIOUS PLATE AND INDENTER MATERIAL COMBINATIONS

\begin{tabular}{|c|c|c|c|c|c|}
\hline Plate & Indenter & $\begin{array}{c}\text { Threshold load, } \\
\text { kgf (lbs) }\end{array}$ & $\begin{array}{c}\text { Peak stress, } \\
\text { GPa (ksi) }\end{array}$ & $\begin{array}{c}\text { Contact dia., } \\
\text { mm (in.) }\end{array}$ & $\begin{array}{c}\text { Avg. stress, } \\
\text { GPa (ksi) }\end{array}$ \\
\hline Stellite 6B & $\mathrm{Si}_{3} \mathrm{~N}_{4}$ & $10(22)$ & $2.06(299)$ & $0.30(0.012)$ & $1.37(199)$ \\
\hline $440 \mathrm{C}$ & $\mathrm{Si}_{3} \mathrm{~N}_{4}$ & $51(112)$ & $3.48(504)$ & $0.52(0.021)$ & $2.32(336)$ \\
\hline $\mathrm{M} 50$ & $\mathrm{Si}_{3} \mathrm{~N}_{4}$ & $150(331)$ & $5.09(738)$ & $0.74(0.029)$ & $3.39(491)$ \\
\hline $60 \mathrm{NiTi}$ & $\mathrm{Si}_{3} \mathrm{~N}_{4}$ & $552(1214)$ & $5.56(806)$ & $1.36(0.054)$ & $3.71(537)$ \\
\hline Stellite 6B & $60 \mathrm{NiTi}$ & $15(33)$ & $1.56(226)$ & $0.42(0.017)$ & $1.04(151)$ \\
\hline $440 \mathrm{C}$ & $60 \mathrm{NiTi}$ & $150(331)$ & $3.33(483)$ & $0.92(0.036)$ & $2.22(322)$ \\
\hline $\mathrm{M} 50$ & $60 \mathrm{NiTi}$ & $501(1102)$ & $5.02(728)$ & $1.37(0.054)$ & $3.35(486)$ \\
\hline $60 \mathrm{NiTi}$ & $60 \mathrm{NiTi}$ & $1512(3327)$ & $5.90(856)$ & $2.19(0.086)$ & $3.94(571)$ \\
\hline
\end{tabular}

A follow-on measurement was made with the Brinell test set up (Fig. 5) in which discrete loads were applied to the plate specimens using $\mathrm{Si}_{3} \mathrm{~N}_{4}$ and $60 \mathrm{NiTi}$ indenter balls at levels below those needed to cause dents. In these tests, first a low load was placed on the indenter balls and then removed. If no dent was observed (visually) a new test was done using a higher load. The process was repeated until the damage threshold load was determined. Table IV gives these threshold loads along with corresponding stress values calculated using the Hertz equations (Ref. 1). These values are of great interest in engineered systems since threshold load and stress are used to determine the machine design, not a hardness number.

These results illustrate the value of using hard but highly elastic materials in concentrated contacts. Stellite $6 \mathrm{~B}$ was indented with $\mathrm{Si}_{3} \mathrm{~N}_{4}$ or $60 \mathrm{NiTi}$ balls at loads above only 10 and $15 \mathrm{~kg}$, respectively. $440 \mathrm{C}$ withstood 51 or $150 \mathrm{~kg}$, and M50 withstood 150 and $500 \mathrm{~kg}$ when loaded with $\mathrm{Si}_{3} \mathrm{~N}_{4}$ and $60 \mathrm{NiTi}$ balls, respectively. Hardened $60 \mathrm{NiTi}$ proved the most dent resistant by far, withstanding $552 \mathrm{~kg}$ against $\mathrm{Si}_{3} \mathrm{~N}_{4}$ and $1509 \mathrm{~kg}$ when contacted by the 60NiTi ball. Clearly, using highly elastic materials like 60NiTi for one or both contacting surfaces leads to dramatically enhanced loading capability. Such loading capability exceeds that expected based upon hardness alone. To better understand the reasons for 60NiTi's exemplary resilience one needs to consider its superelastic nature and this is best illustrated through the standard compression test.

\section{Compression Test}

The most generally accepted and broadly understood test data comes from simple compression tests conducted on small cylindrical samples. In this test $5 \mathrm{~mm}$ diameter by $10 \mathrm{~mm}$ long cylinders of $60 \mathrm{NiTi}$ were placed between hardened steel anvils in a servo-hydraulic test frame and deformed in displacement control at an initial strain rate of approximately $1 \times 10^{-4} \mathrm{~s}^{-1}$ while measuring strain as a function of applied stress. Repeated cycles were imposed on the same sample to a constant upper stress level determined from previous compression tests. The data is presented as stress versus strain from which the strength, apparent stiffness and recoverable strain levels were assessed. Figure 6 shows the compression test results for 6 repeated stress cycles on the same hot-rolled plus hardened specimen.

When initially loaded in compression, the 60NiTi sample deformed as the load increased in a slightly non-linear fashion up to the load limit capability of the test fixtures, in this case $2500 \mathrm{MPa}$. When the load was reduced, the majority of the strain was recovered, save for one percent, most likely due to plastic deformation. Upon repeated loading the sample deformed reproducibly between the same limits with only a small hysteresis observed between the loading and unloading segments. Subsequent loading cycles showed little deviation from this reproducible behavior.

Two important aspects of the material behavior were revealed from this test. The first is that a small amount ( $\sim 1$ percent) of non-recoverable strain occurred during the very first loading event. The implications of this one-time initial 1 percent non-recoverable strain will be discussed later. The other aspect is that $60 \mathrm{NiTi}$ withstood exceedingly large amounts of recoverable strain over repeated cycles with no observed degradation. Typical bearing steels can withstand only a few tenths of 1 percent strain with 


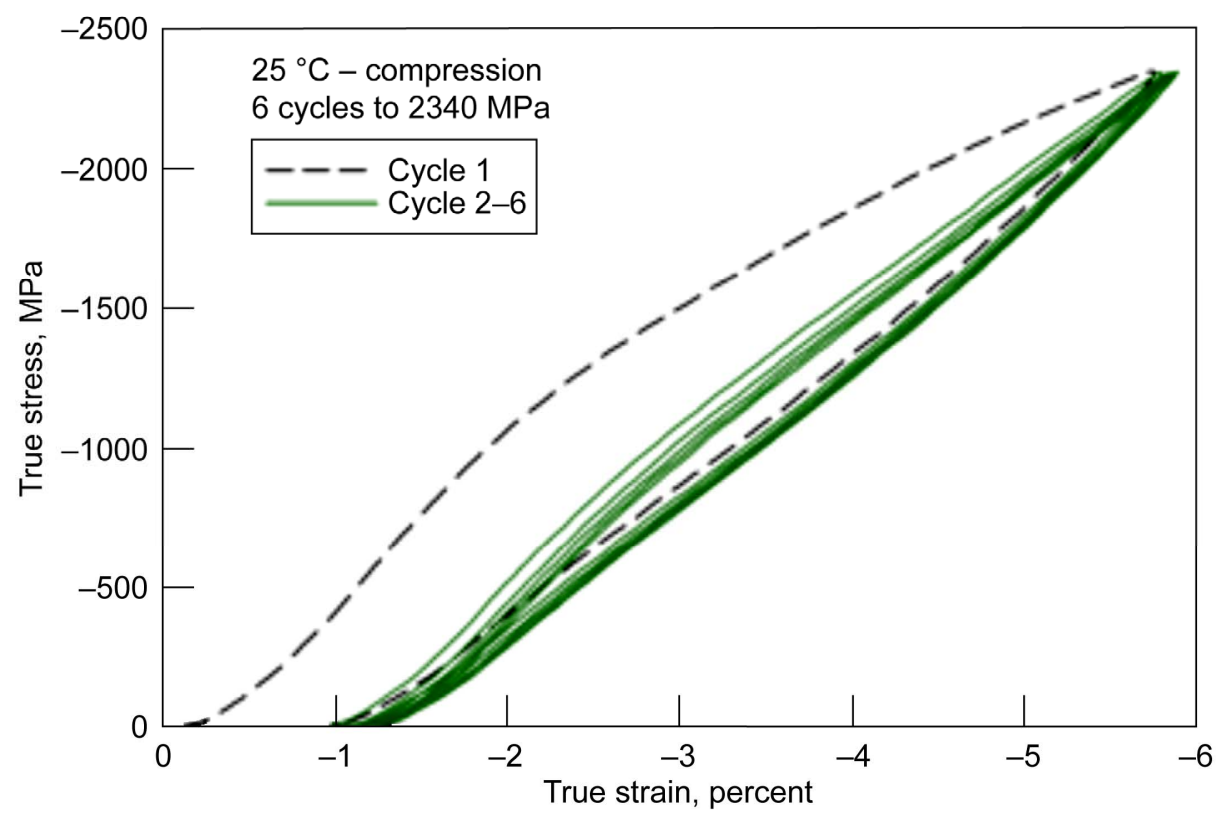

Figure 6.-Compression behavior of hot-rolled plus hardened 60NiTi. Note: The maximum stress level is limited by test fixtures, not the specimen.

full recovery when the load is removed. The extraordinary levels of recoverable strain observed for $60 \mathrm{NiTi}$ is typical for superelastic materials and helps explain why such high loads were required to achieve a dent in the Brinell test.

\section{Rolling Contact Fatigue Test}

Rolling contact bearing materials must possess acceptable rolling contact fatigue (RCF) behavior. For evaluating RCF performance 60NiTi rods were wire Electrode Discharge Machine (EDM) cut from the hot-rolled plus hardened plate and ground and lapped to achieve an acceptable surface finish (roughness $\sim 0.4 \mu \mathrm{m} \mathrm{rms}$ ). These were placed into a standard Federal Mogul style tester, lubricated by mineral oil, and loaded by three tool steel balls at three load levels corresponding to 266, 356, and $429 \mathrm{ksi}$ contact stress. Test speed was $3600 \mathrm{rpm}$ and time to first spall was evaluated as indicated by accelerometer detection. The results are summarized in Table V. For comparison purposes, high quality, fully commercialized bearing steels can withstand about $500 \mathrm{ksi}$ without experiencing fatigue failures.

The $60 \mathrm{NiTi}$ results varied widely. At the highest stress, $429 \mathrm{ksi}$, life ranged from 2.2 to $8.4 \mathrm{~h}$. Clearly, this stress level exceeds the capability of the currently available rods. At $356 \mathrm{ksi}$, the life ranged from a low of $4.2 \mathrm{~h}$ to well over $169 \mathrm{~h}$ in one test. At the lowest stress, $266 \mathrm{ksi}$, life ranged from $13.8 \mathrm{~h}$ to greater than $840 \mathrm{~h}$. In this latter case, there was no failure and the test was intentionally ended and the fatigue life was deemed essentially infinite. Examination of the spalls and close scrutiny of the rods using crosssectional metallography coupled with SEM and EDS-Xray analyses helped elucidate the sporadic fatigue behavior observed.

Figures 7 and 8 show images of the wear tracks following rolling tests at 266 and $429 \mathrm{ksi}$, respectively. Under the low load the wear was a mild polishing type wear. At the higher load, the failure appeared as a classical fatigue spall likely originating at subsurface flaws, a characteristic common for hard, limited ductility materials undergoing repeated contact. Cross-section images, of the microstructures shown previously in Figure 4(a), revealed stringers of oxides and other hard inclusions, residual porosity and multiple coarse phases within the NiTi matrix. The microstructure after the hardening treatment was essentially the same as that shown in Figure 9. 
TABLE V.-PRELIMINARY ROLLING CONTACT FATIGUE (RCF) LIFE FOR 60NiTi RODS (LOADED AGAINST M50 STEEL BALLS, 3600 RPM, MINERAL OIL LUBRICANT)

\begin{tabular}{|c|c|c|}
\hline $\begin{array}{c}\text { RCF stress } \\
\text { level, Ksi }\end{array}$ & $\begin{array}{c}\text { Wear track } \\
\text { width, } \mu \mathrm{m}\end{array}$ & $\begin{array}{c}\text { RCF Life, } \\
\text { hr }\end{array}$ \\
\hline 429 & $850+/-18$ & $5.7+/-3.2$ \\
\hline 356 & $701-/-25$ & 5.4 (typical) \\
\hline 266 & 540 & 13.8 to 841(no failure) \\
\hline
\end{tabular}

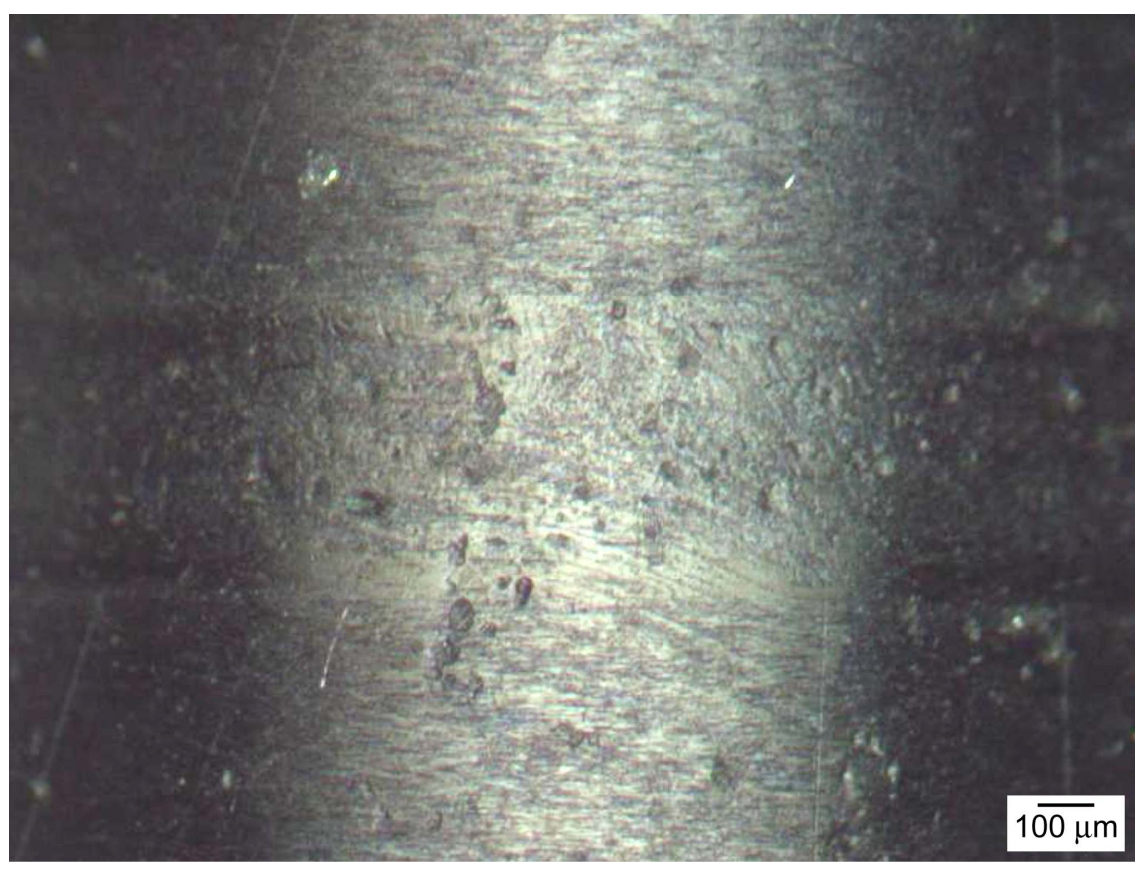

Figure 7.-Wear track surface following RCF test at $360 \mathrm{ksi}$, no failure observed.

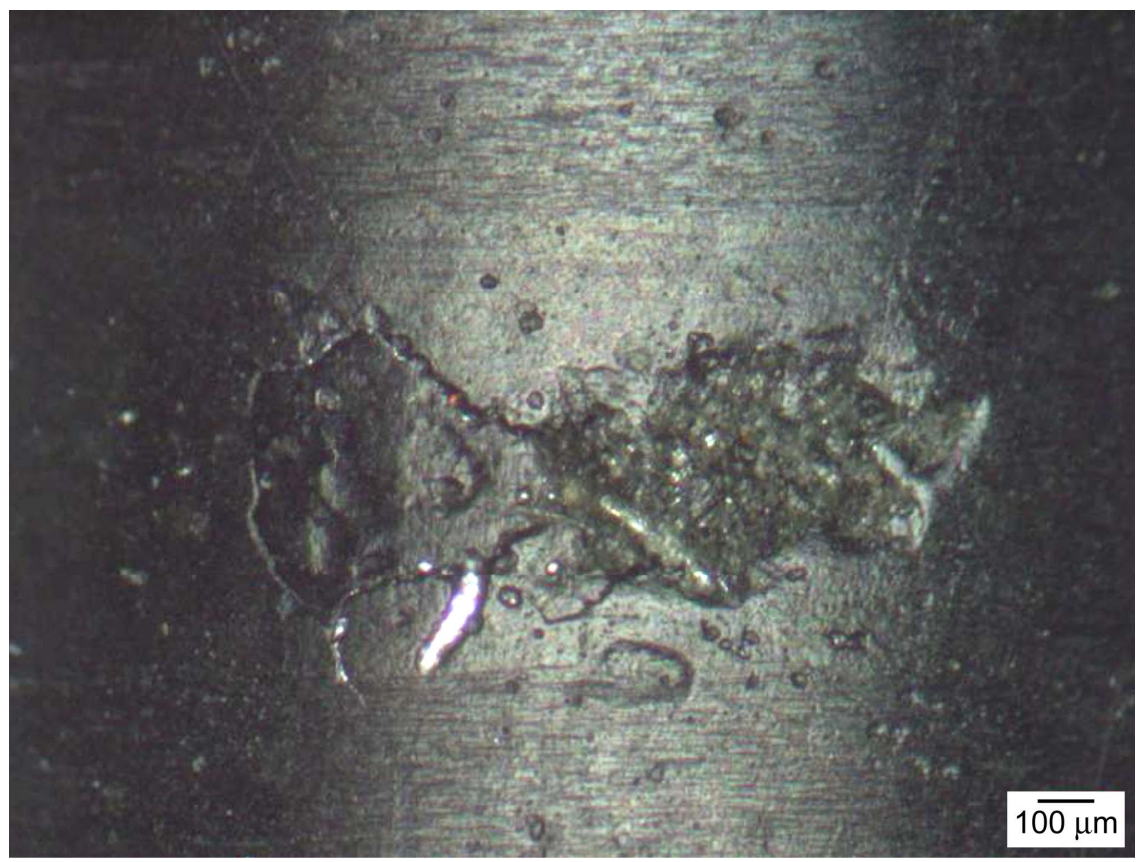

Figure 8.-Spall damage on a hardened 60NiTi rod surface following testing at $580 \mathrm{ksi}$. 


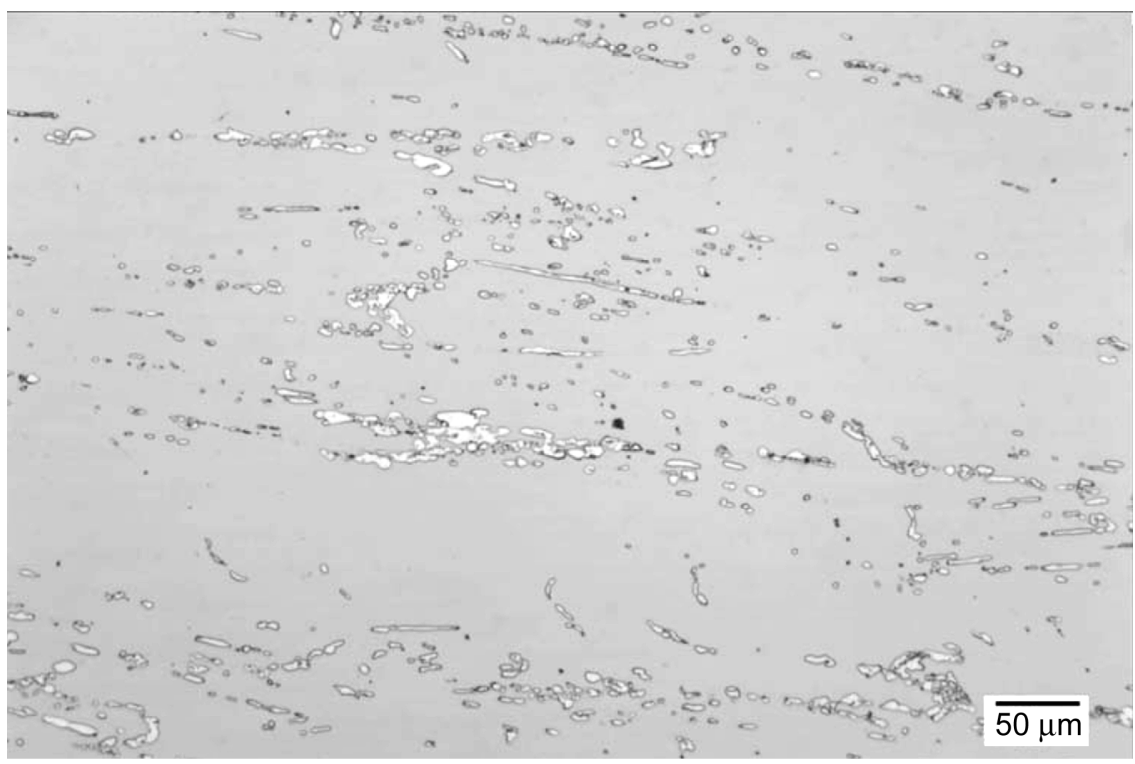

Figure 9.-Optical micrograph of the cross-section of one of the hardened $60 \mathrm{NiTi}$ RCF rods showing voids and second phase precipitates.

These flaws and the large variability in their size are undoubtedly contributing factors to the scatter and early failures seen in many of the tests. It is likely that those samples that exhibited superior fatigue performance, nearing that of commercial steels, had smaller subsurface defects than those with shorter lives. Further fatigue tests are planned utilizing higher quality specimens made by powder metallurgy and other processing routes that will reduce the size and density of such defects. Despite the variability, even the current $60 \mathrm{NiTi}$ rods can be considered for modestly loaded applications with respect to fatigue. Furthermore, given the poor quality of the tested material in terms of microstructure, the fatigue data is actually quite encouraging.

\section{SOT Tribology Testing}

The tribological behavior of 60NiTi in a lubricated rolling contact was evaluated using a Spiral Orbit Tribometer (SOT). In this test, a single powder metallurgy processed 60NiTi ball was loaded between two rotating $440 \mathrm{C}$ steel disks, lubricated with synthetic oil and tested in a vacuum. The $60 \mathrm{NiTi}$ ball was marginally lubricated with a small quantity $(\sim 25 \mu \mathrm{g})$ of oil. The test conditions fell within the boundary lubrication regime that helped assess the tribological and tribo-chemical compatibility of the material.

The SOT, depicted in Figure 10 and described in detail elsewhere (Refs. 12 and 15), is basically a thrust bearing with one ball and flat races (plates). One of the plates was stationary and the other rotated to drive the ball into an orbit that was an opening spiral. The ball contacted a "guide plate" at the end of each orbit, which forced the ball back into its initial orbital radius. A piezoelectric force transducer supporting the guide plate sensed the frictional force developed on the ball as it slid on the rotating plate. During this contact, the coefficient of friction was obtained from this force and the load imposed on the system. Prior to testing, the ball specimen was dipped into a dilute oil-solvent solution depositing a thin $(\sim 25 \mu \mathrm{g})$ volume of lubricant onto the surface. Tests were typically run for several thousand cycles until the oil was consumed and friction rose. The number of test cycles, prior to a steep rise in friction, was used as the indication of tribological performance.

Under these conditions, considered representative of precision bearings, performance (life and friction) was comparable to that observed with $440 \mathrm{C}$ bearing balls. Figure 11 shows the friction results from several comparative tests. The results clearly show that $60 \mathrm{NiTi}$ met or exceeded the tribological capabilities of the standard 440C stainless steel. Typical lubricant lifetimes were approximately 30,000 to 60,000 revolutions indicating a slow lubricant consumption rate. In one test (not shown) using both 

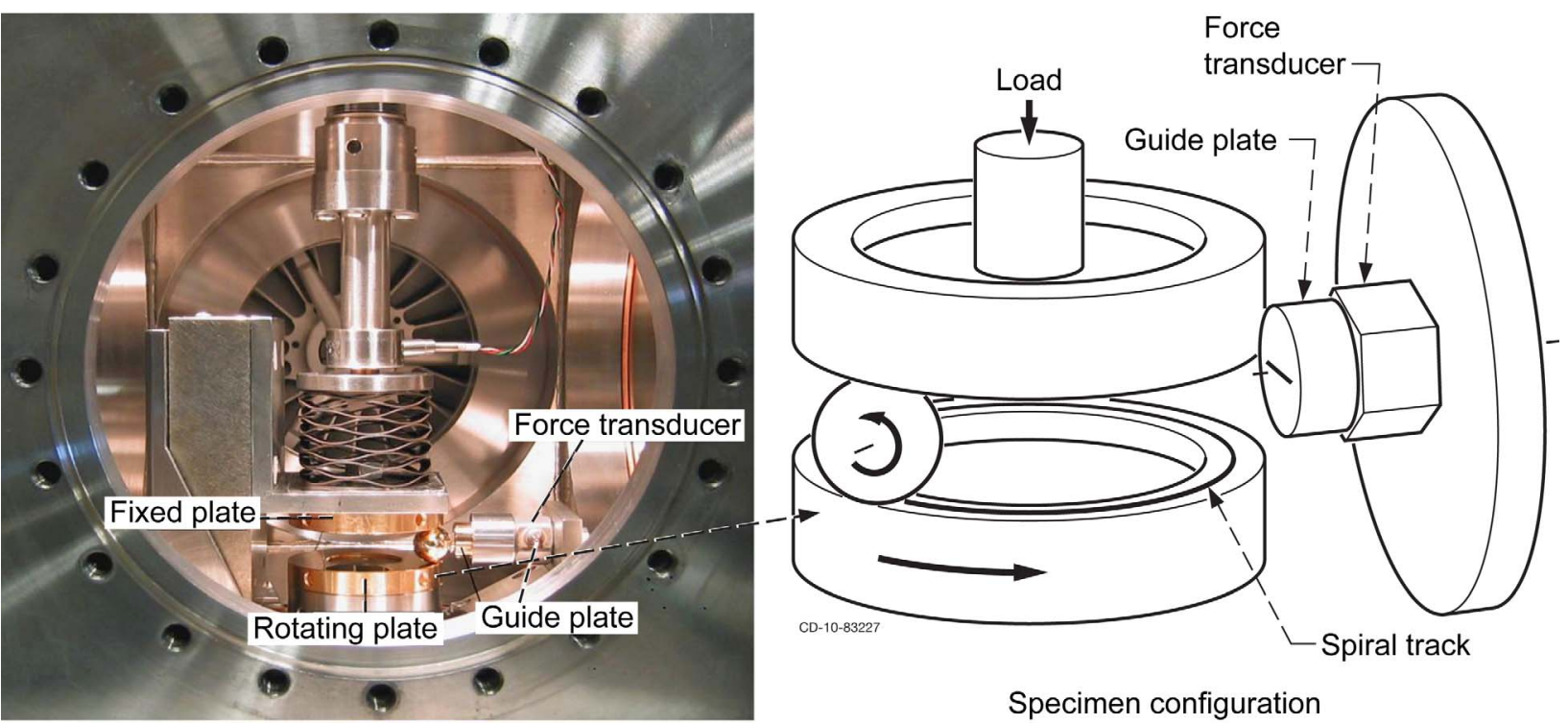

Figure 10.-Spiral Orbit Tribometer (SOT) used to evaluate the relative lubricant life of various alloys under simulated bearing conditions.

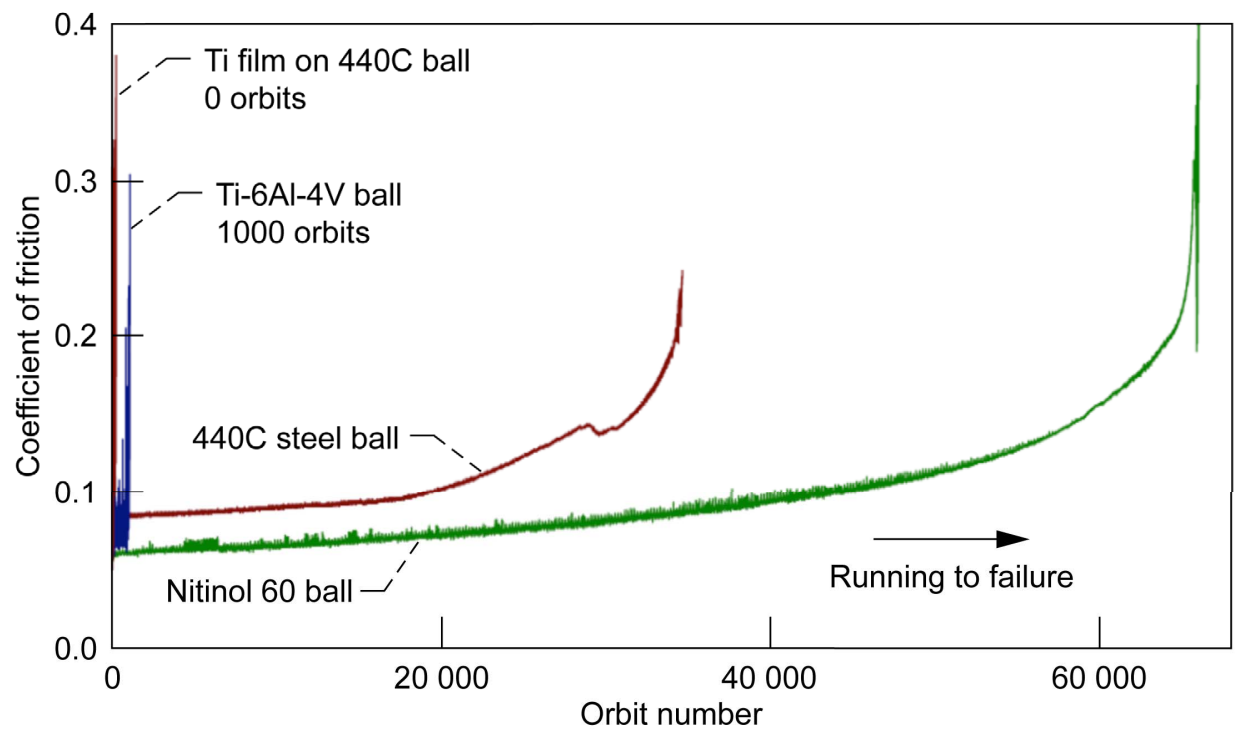

Figure11._SOT results for various balls running against $440 \mathrm{C}$ plates lubricated with Pennzane 2001A oil.

$60 \mathrm{NiTi}$ plates and ball, the rig was permitted to run well beyond the complete consumption of lubricant. The friction climbed to a coefficient of around 0.35 but was stable and no galling tendencies were observed.

Also shown in Figure 11 are SOT results of solid Ti-6Al-4V balls and 440C balls that had been previously sputter coated with a thin film of pure titanium. Both of these ball material configurations aggressively degraded the lubricant and experienced high friction and seizure within a few dozen revolutions. 


\section{Discussion}

The primary goal of this investigation was to assess the potential for highly elastic, hard materials like $60 \mathrm{NiTi}$ to satisfy the demands of tribological contacts and to withstand extreme loading events in mechanical systems and remain undamaged. A series of novel and conventional experimental measurements were used to provide input for such an assessment. The results of these experiments are remarkably consistent and support the validity of using hard superelastic materials for mechanical components.

The SOT tribology test results indicate that $60 \mathrm{NiTi}$ exhibits behavior comparable to high performance bearing steels. This result is welcome and somewhat unexpected given the significant differences in the surface chemistry between steels and 60NiTi. The long lubricant lifetimes exhibited may also indicate that further improvements through more appropriate choice of lubricant or through the use of additives tailored for nickel and titanium metallurgy may be possible. In addition, the tribology results indicate the potential for reduced friction.

Figure 12 shows the friction coefficients for $440 \mathrm{C}$ and $60 \mathrm{NiTi}$ balls rolling on $440 \mathrm{C}$ plates. Friction for $60 \mathrm{NiTi}$ is consistently lower than for $440 \mathrm{C}$. While the exact reason for the lower friction with $60 \mathrm{NiTi}$ is not yet fully understood, it may be related to the superelastic behavior of the 60 N.T. ball in that the normal elastic deformation of the surfaces as they contact is better recovered than steel ball materials which experience deformation losses (hysteresis). Based upon these considerations, lower friction and higher overall efficiency of bearings, gears, drives and mechanical components may be expected.

The results from the most basic standard Rockwell and Brinell hardness tests offer little evidence that $60 \mathrm{NiTi}$ differed in any appreciable extent from a common bearing material. 60NiTi's Brinell hardness was around 530 and its Rockwell C hardness was 60 to 62 . These values compare closely to M50 and $440 \mathrm{C}$ tool steels and indicate good prospects for use in highly concentrated contacts.

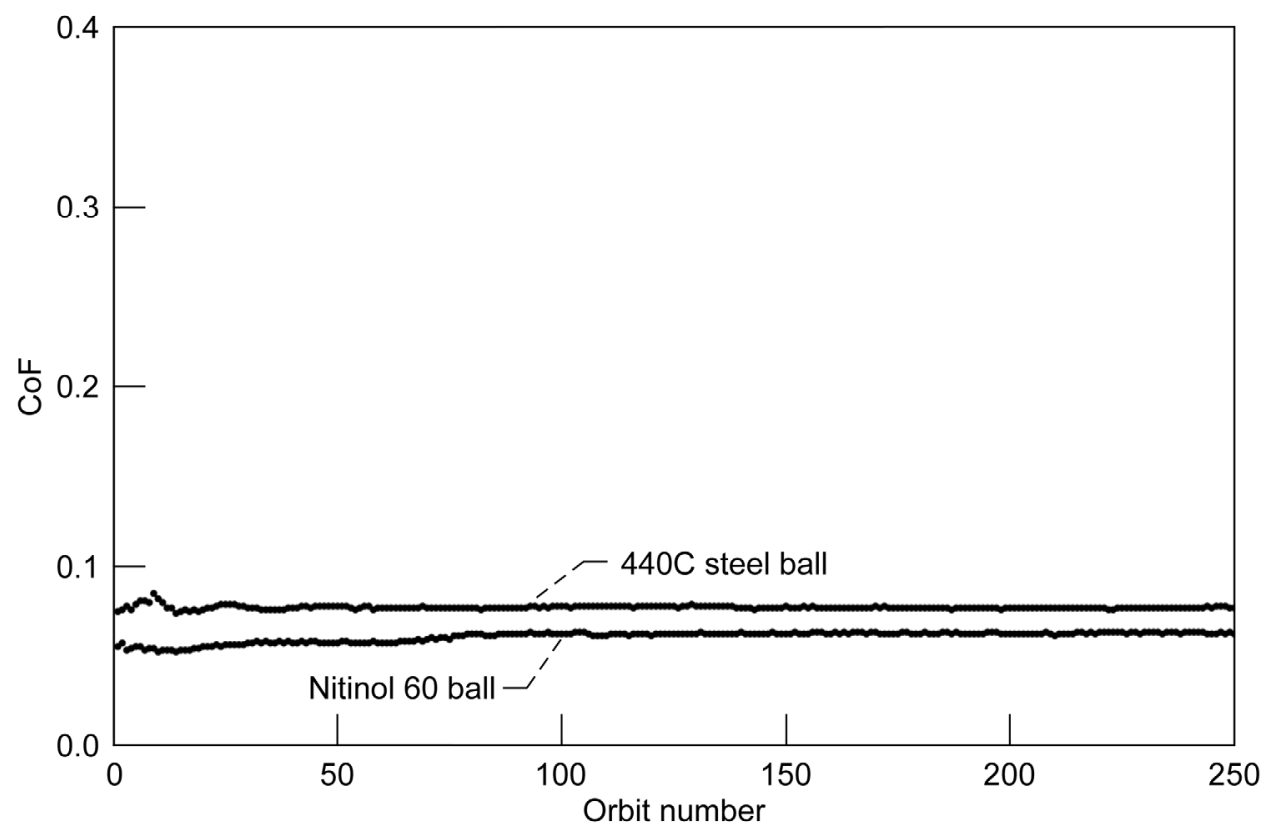

Figure 12.-Initial friction traces for a $440 \mathrm{C}$ steel ball and a $60 \mathrm{NiTi}$ ball rolling against $440 \mathrm{C}$ plates. Both balls have been lubricated with $\sim 25 \mu \mathrm{g}$ oil. 
The conventional compression test results illustrated the unique and unusual deformation behavior of $60 \mathrm{NiTi}$. The compressive behavior of $60 \mathrm{NiTi}$ differed substantially from other hardened bearing materials. Hard bearing materials have low strain to failure, typically 1 percent or less. They are stiff, unyielding, and brittle. $60 \mathrm{NiTi}$, in contrast, is superelastic. Its stress strain behavior is complex as shown in Figure 6. On the first loading cycle, strain builds slowly over a broad strain range. At more than 5 percent strain and $2.5 \mathrm{GPa}$ load, the test fixture had reached its contact load limit. The load was then reduced and when fully unloaded we can see that over 4 percent of the strain was recovered. Subsequent loading cycles exhibited only fully recoverable "elastic-like" response. In reality, this was superelastic behavior due to the formulation of stress-induced martensite during loading and its transformation back to austenite during unloading. In the current set-up, the maximum allowable strain in compression was not reached or measured. In comparison to conventional bearing steels, $60 \mathrm{NiTi}$ exhibited remarkably high levels of recoverable strain. It is hard, yet combines a low apparent modulus and an extraordinarily extended region of recoverable deformation. Based upon the slope of the stress-strain curve and the result from the Brinell threshold load limit tests that showed permanent deformation only above $5.7 \mathrm{GPa}$, one can extrapolate that the recoverable elastic strain limit lies near 10 percent strain. This will need to be verified in future testing.

With respect to engineering applications, the superelastic behavior of 60NiTi offers significant benefit. Highly deformable materials that can also withstand high levels of recoverable strain are more forgiving to overload events. Under extreme loads, such surfaces will momentarily and elastically deform creating a relatively large contact area with commensurately low contact stress and reduced chance for permanent damage. Highly recoverable materials can also better withstand debris-induced damage. For instance in a ball bearing, the superelastic nature of $60 \mathrm{NiTi}$ can allow a ball to overrun a hard debris particle by temporarily deforming rather than incurring a permanent dent through plastic flow. In order to realize this benefit, some pre-straining (e.g., coining or forging) will be required before a component reaches its finished geometry. This is necessary to eliminate the potential for plastic deformation as shown in the first loading cycle in Figure 6. Such treatment is common with high performance materials and for $60 \mathrm{NiTi}$ will ensure that all deformation that occurs in use will be of the fully recoverable type.

The Brinell style indentation experiments used to determine the load threshold for permanent damage provides compelling evidence that a superelastic material can contribute to improved mechanical components and devices. The threshold load for damage for the 60NiTi system (ball and plate) is at least an order of magnitude higher than the best hybrid bearing system currently in use. The reason for this behavior can be best understood through the contact stress modeling embodied in the hertz equations. For a given contact geometry, the stress between a ball and plate is dictated solely by the elastic modulus of the ball, plate, and the load. Table IV lists the results. The lower stiffness of $60 \mathrm{NiTi}$ results in a larger deformed contact area and thus the peak and average stresses are reduced compared to materials with higher elastic moduli. NITINOL's superelastic behavior enhances this effect in two ways. First its superelasticity causes it to appear to have an even smaller "effective" modulus, further reducing peak stresses. And second, its ability to recover extremely large strains results in extraordinarily high damage threshold loads. The behavior of $60 \mathrm{NiTi}$, as observed in this series of experiments, is perfectly understandable once these effects are taken into account. The combination of low modulus and high recoverable strain provides load tolerance while the high hardness gives good wear resistance.

In effect, the use of a high Modell material as postulated by Oberle in the middle of the last century appears quite valid. 60NiTi's additional attractive properties such as low density, intrinsic corrosion resistance and non-magnetic properties add to the compelling case that it is a breakthrough in mechanical component materials. Figure 13 graphically depicts the combined benefits of this novel approach with respect to load damage tolerance and environmental corrosion. 


\section{Damage Threshold Load Capacity (1/2 in. dia. ball pressed into plate)}

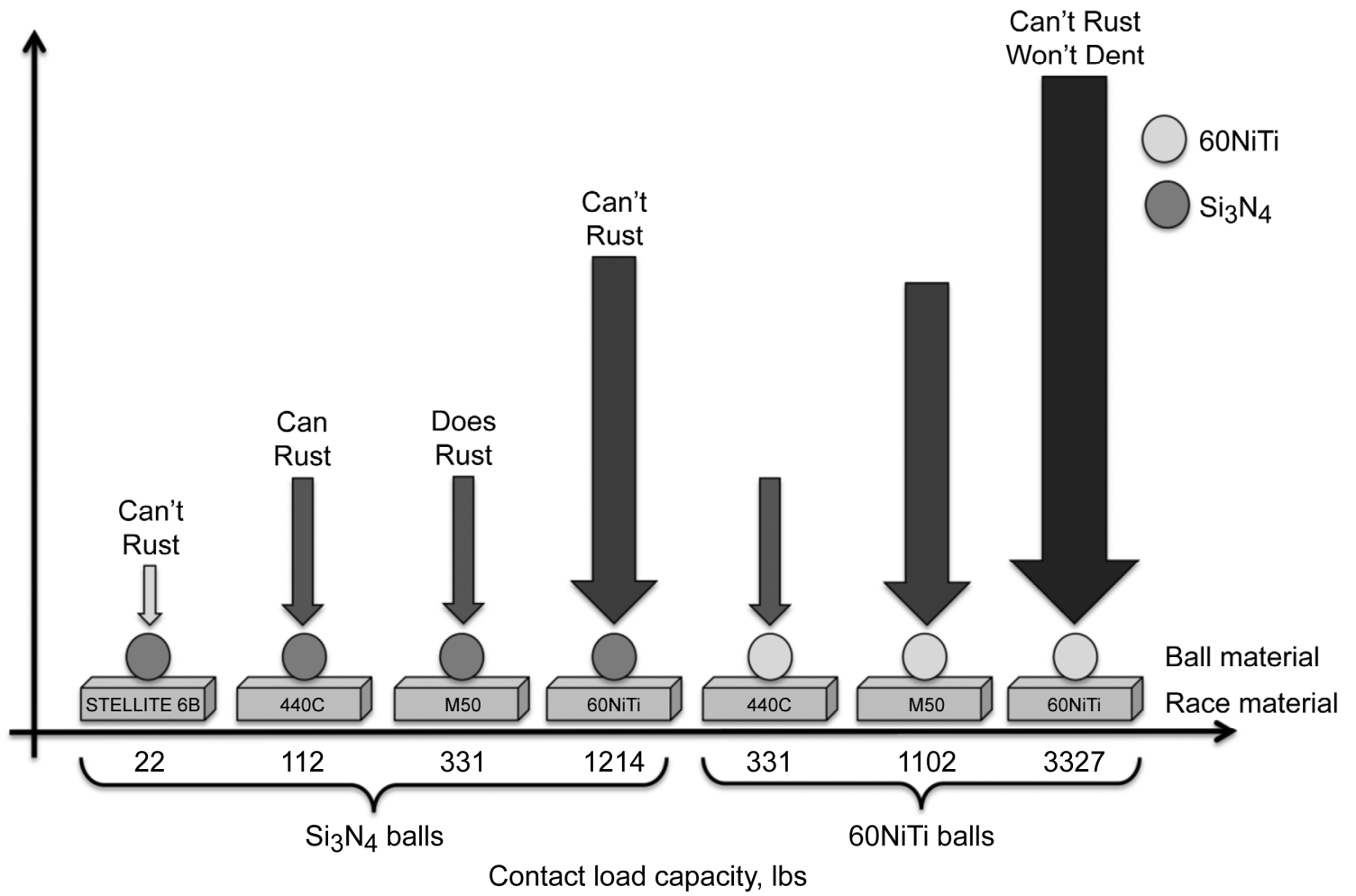

Figure 13.-Graphical depiction of the indentation load tolerance of various bearing material combinations.

\section{Summary Remarks}

This paper presents a novel approach to improve the resiliency, debris and shock load tolerance and efficiency of mechanical components by the adoption of emerging hard yet superelastic construction materials. Through a series of conventional and unconventional materials tests it has been shown that low modulus, hardened superelastic materials, such as $60 \mathrm{NiTi}$, can withstand extreme loading conditions without incurring permanent surface damage. In contrast, bearing and gear materials currently in widespread use readily sustain damage at much lower load levels. The test results, when taken together, indicate that the superior performance of loaded contacts made from this hard superelastic material is directly related to it's unique combination of high hardness, significantly reduced "effective" modulus and extremely high levels of recoverable strain (superelastic behavior). Based upon the investigations, the following specific remarks are made:

- The use of hardened materials with modest effective elastic modulus that exhibit superelastic behavior results in significantly enhanced load capability for contacting surfaces.

- The extreme levels of recoverable deformation that occur when superelastic, low effective modulus materials, like 60NiTi, are placed under heavy contact loads results in larger hertzian contact areas that effectively distribute the load, reduce peak and average stresses and prevent contact damage.

- $60 \mathrm{NiTi}$ appears to undergo a small amount of irrecoverable plastic deformation during initial loading. After that, it exhibits remarkably reversible, superelastic strain behavior as evidenced by cyclic compression tests. These observations indicate that some mechanical working of the material, such as coining or forging, may be desirable prior to use. 
- When the exemplary load tolerance of $60 \mathrm{NiTi}$ is taken with its previously proven benign tribological behavior a compelling case for significantly enhanced machine component performance is expected.

- When one considers that the 60NiTi material is the least complex superelastic alloy currently available, it is likely that through alloying and other development, materials with greatly enhanced performance will emerge.

Though much more research will be required to understand the $60 \mathrm{NiTi}$ material and its metallurgical relatives, the results obtained thus far point to a very bright future for many applications where extreme loading is unavoidable. Further, it is anticipated that many other materials with similar superelastic behavior will emerge to greatly expand the tools available to mechanical design engineers for problem solving and technological development.

\section{References}

1. Hertz, H.: "On the Contact of Rigid Elastic Solids and on Hardness," Verh. Ver. Beford, GewFleiss, November 1882.

2. Dowson, D.: History of Tribology, Chapter 9, "The Industrial Revolution," pp. 187-285, Professional Engineering Publishing Limited, London, 1998.

3. Stone, D.H. and Steele, R.K., "The Effect of Mechanical Properties Upon the Performance of Railroad Rails" Rail Steels-Developments, Processing and Use, ASTM STP 644, D.H. Stone and G.G. Knupp, Editors, American Society for Testing Materials, 1978, pp. 21-62.

4. Palmgren, A.: Ball and Roller Bearing Engineering, Chapter 8, "Bearing Failures," pp. 217-225, $3^{\text {rd }}$ edition, SKF Industries, Philadelphia, PA, 1959.

5. Oberle, T.L.: "Properties Influencing Wear of Metals," Journal of Metals, June 1951.

6. Matthews, A. and Leyland, A.: "Design Criteria for Wear-Resistant Nanostructured and Glassy-Metal Coatings," Surface Coatings and Technology, 177-178 (2004), pp. 317-324.

7. Carter, D.L.: "Status of the Regenerative ECLSS Water Recovery System," NASA Report 2009-012352, NASA Marshall Space Flight Center.

8. D.E., Hodgson, M.H. Wu, and R.J. Biermann, "Shape Memory Alloys," Metals Handbook, Volume 2, $10^{\text {th }}$ Edition, pp. 897-902, ASM International, Metals Park, Ohio, 1990.

9. S.A. Shabalovskaya: "Surface, Corrosion and Biocompatibility Aspects of NITINOL as an Implant Material," Bio-Medical Materials and Engineering, Volume 12, 2002, pp. 69-109.

10. A. Stebner, S.A. Padula, R.D. Noebe, and D.D. Quinn, "Characterization of $\mathrm{Ni}_{19.5} \mathrm{Ti}_{50.5} \mathrm{Pd}_{25} \mathrm{Pt}_{5} \mathrm{High}$ Temperature Shape Memory Alloy Springs and Their Potential Application in Aeronautics," Proc. of SPIE Vol. 6928, 69280X, 2008.

11. J.H. Mabe, F.T. Calkins, and G.W. Butler, "Boeings Variable Geometry Chevron, Morphing Aerostructure for Jet Noise Reduction," American Institute of Aeronautics and Astronautics, AIAA2006-2142, 2006.

12. DellaCorte, C., Pepper, S.V., Noebe, R., Hull, D.R. and Glennon, G.: "Intermetallic Nickel-Titanium Alloys for Oil-Lubricated Bearing Applications," NASA/TM-2009-215646.

13. Pepper, S.V., DellaCorte, C., Noebe, R., Hull, D.R. and Glennon, G.: "NITINOL 60 as a Material for Spacecraft Triboelements," presented at the ESMATS 13 Conference, Vienna, Austria, September 2009.

14. M.D. McNeese, D.C. Lagoudas, and T.C. Pollock; "Processing of TiNi from Elemental Powders by Hot Isostatic Pressing," Materials Science and Engineering A280 (2000), pp. 334-348.

15. W.R. Jones, Jr., S.V. Pepper, M.J. Jansen, Q.N. Nguyen, E.P. Kingsbury, S.H. Loewenthal, and R.E. Predmore: "A New Apparatus to Evaluate Lubricants for Space Applications-The Spiral Orbit Tribometer (SOT)," NASA/TM-2000-209935. 


\begin{tabular}{|c|c|c|}
\hline \multicolumn{2}{|c|}{ REPORT DOCUMENTATION PAGE } & $\begin{array}{l}\text { Form Approved } \\
\text { OMB No. 0704-0188 }\end{array}$ \\
\hline \multicolumn{3}{|c|}{$\begin{array}{l}\text { The public reporting burden for this collection of information is estimated to average } 1 \text { hour per response, including the time for reviewing instructions, searching existing data sources, gathering and maintaining the } \\
\text { data needed, and completing and reviewing the collection of information. Send comments regarding this burden estimate or any other aspect of this collection of information, including suggestions for reducing this } \\
\text { burden, to Department of Defense, Washington Headquarters Services, Directorate for Information Operations and Reports (0704-0188), } 1215 \text { Jefferson Davis Highway, Suite } 12204 \text {, Alrington, VA } 222022-402 \text {. } \\
\text { Respondents should be aware that notwithstanding any other provision of law, no person shall be subject to any penalty for failing to comply with a collection of information if it does not display a currently valid OMB } \\
\text { control number. } \\
\text { PLEASE DO NOT RETURN YOUR FORM TO THE ABOVE ADDRESS. }\end{array}$} \\
\hline $\begin{array}{l}\text { 1. REPORT DATE (DD-MM-YYYY) } \\
01-08-2011\end{array}$ & $\begin{array}{l}\text { 2. REPORT TYPE } \\
\text { Technical Memorandum }\end{array}$ & 3. DATES COVERED (From - To) \\
\hline \multirow{3}{*}{\multicolumn{2}{|c|}{$\begin{array}{l}\text { 4. TITLE AND SUBTITLE } \\
\text { Resilient and Corrosion-Proof Rolling Element Bearings Made From Superelastic Ni-Ti } \\
\text { Alloys for Aerospace Mechanism Applications }\end{array}$}} & 5a. CONTRACT NUMBER \\
\hline & & 5b. GRANT NUMBER \\
\hline & & 5c. PROGRAM ELEMENT NUMBER \\
\hline \multirow{3}{*}{\multicolumn{2}{|c|}{$\begin{array}{l}\text { 6. AUTHOR(S) } \\
\text { DellaCorte, Christopher; Noebe, Ronald, D.; Stanford, Malcolm, K.; Padula, Santo, A. }\end{array}$}} & 5d. PROJECT NUMBER \\
\hline & & 5e. TASK NUMBER \\
\hline & & $\begin{array}{l}\text { 5f. WORK UNIT NUMBER } \\
\text { WBS 877868.02.07.03.01.03.04 }\end{array}$ \\
\hline \multicolumn{2}{|c|}{$\begin{array}{l}\text { 7. PERFORMING ORGANIZATION NAME(S) AND ADDRESS(ES) } \\
\text { National Aeronautics and Space Administration } \\
\text { John H. Glenn Research Center at Lewis Field } \\
\text { Cleveland, Ohio 44135-3191 }\end{array}$} & $\begin{array}{l}\text { 8. PERFORMING ORGANIZATION } \\
\text { REPORT NUMBER } \\
\text { E-17678-1 }\end{array}$ \\
\hline \multirow{2}{*}{\multicolumn{2}{|c|}{$\begin{array}{l}\text { 9. SPONSORING/MONITORING AGENCY NAME(S) AND ADDRESS(ES) } \\
\text { National Aeronautics and Space Administration } \\
\text { Washington, DC 20546-0001 }\end{array}$}} & $\begin{array}{l}\text { 10. SPONSORING/MONITOR'S } \\
\text { ACRONYM(S) } \\
\text { NASA }\end{array}$ \\
\hline & & $\begin{array}{l}\text { 11. SPONSORING/MONITORING } \\
\text { REPORT NUMBER } \\
\text { NASA/TM-2011-217105 }\end{array}$ \\
\hline \multicolumn{3}{|c|}{$\begin{array}{l}\text { 12. DISTRIBUTION/AVAILABILITY STATEMENT } \\
\text { Unclassified-Unlimited } \\
\text { Subject Categories: } 37 \text { and } 26 \\
\text { Available electronically at http://www.sti.nasa.gov } \\
\text { This publication is available from the NASA Center for AeroSpace Information, 443-757-5802 }\end{array}$} \\
\hline
\end{tabular}

\section{SUPPLEMENTARY NOTES}

\section{ABSTRACT}

Mechanical components (bearings, gears, mechanisms) typically utilize hard materials to minimize wear and attain long life. In such components, heavily loaded contact points (e.g., meshing gear teeth, bearing ball-raceway contacts) experience high contact stresses. The combination of high hardness, heavy loads and high elastic modulus often leads to damaging contact stress. In addition, mechanical component materials, such as tool steel or silicon nitride exhibit limited recoverable strain (typically less than 1 percent). These material attributes can lead to Brinell damage (e.g., denting) particularly during transient overload events such as shock impacts that occur during the launching of space vehicles or the landing of aircraft. In this paper, a superelastic alloy, $60 \mathrm{NiTi}$, is considered for rolling element bearing applications. A series of Rockwell and Brinell hardness, compressive strength, fatigue and tribology tests are conducted and reported. The combination of high hardness, moderate elastic modulus, large recoverable strain, low density, and intrinsic corrosion immunity provide a path to bearings largely impervious to shock load damage. It is anticipated that bearings and components made from alloys with such attributes can alleviate many problems encountered in advanced aerospace applications.

\section{SUBJECT TERMS}

Bearings; Gears; Mechanical components

\begin{tabular}{|c|c|c|c|c|c|}
\hline \multicolumn{3}{|c|}{ 16. SECURITY CLASSIFICATION OF: } & \multirow{2}{*}{$\begin{array}{l}\text { 17. LIMITATION OF } \\
\text { ABSTRACT } \\
\text { UU }\end{array}$} & \multirow{2}{*}{$\begin{array}{l}\text { 18. NUMBER } \\
\text { OF } \\
\text { PAGES } \\
23\end{array}$} & \multirow{2}{*}{$\begin{array}{l}\text { 19a. NAME OF RESPONSIBLE PERSON } \\
\text { STI Help Desk (email:help@sti.nasa.gov) } \\
\text { 19b. TELEPHONE NUMBER (include area code) } \\
\text { 443-757-5802 }\end{array}$} \\
\hline $\begin{array}{l}\text { a. REPORT } \\
U\end{array}$ & $\begin{array}{l}\text { b. ABSTRACT } \\
\text { U }\end{array}$ & $\begin{array}{l}\text { c. THIS } \\
\text { PAGE } \\
\text { U }\end{array}$ & & & \\
\hline
\end{tabular}



